\title{
Decentering Egyptian Historiography: Provincializing Geographies, Methodologies, and Sources
}

\author{
Lucia Carminati ${ }^{1}$ and Mohamed Gamal-Eldin ${ }^{2}$ \\ ${ }^{1}$ History Department, Texas Tech University, Lubbock, TX, 79409, USA and ${ }^{2}$ Urban Systems-History, New Jersey Institute of \\ Technology/Rutgers-Newark, Newark, NJ, 07102, USA \\ Corresponding authors. Email: lucia.carminati@ttu.edu and mg369@njit.edu
}

"They say the city never sleeps, they say it bursts at the seams. The city rotates and revolves. The city branches out. The city beats, the city bleeds." This unnamed city is Cairo, Umm al-Dunya or "mother of the world," at once a vibrant character and the pulsating backdrop of Ahmed Naji's scandal-rousing Istikhdam al-Hayat (Using Life) and countless other works in Egyptian literature. ${ }^{1}$ Cairo, Amitav Ghosh has argued in his autobiographical chronicle of historical research and anthropological fieldwork in the Egyptian Delta in 1980 and beyond, is "Egypt's own metaphor for itself." If that is the case, what does this sprawling and pervasive synecdoche reveal and what does it obscure?

This roundtable brings together five eminent scholars of modern Egypt to ask whether and how the historiography can be budged from its Cairo-centered (and, to a lesser extent, Alexandria-centered) pivot. Collectively, these authors prod the meanings and implications of both center and periphery, upend the notions of an inherent dichotomy between the two and a monolithic hegemony of the former, and trespass merely geophysical distinctions. What thematic vistas and methodological approaches can more effectively unsettle conventional cores? How can slanted perspectives or unexpected points of view change the way we see the whole?

After all, as suggested by French geographer François Moriconi-Ebrard with yet another metaphor, the white margins of a written page are adjacent but external to the central text and, at once, they filter and frame it. ${ }^{3}$ Marginal spaces potentially alter the so-called core, or at least can affect the way we approach it. If looked at up close, Ghosh himself points out, Cairo, like Delhi or Rome, is actually not so much a single city as an archipelago of townships, founded on neighboring sites. ${ }^{4}$ Within each single site, migration and circulation bring different histories together. The Alexandria of Idwar al-Kharrat, for example, brims with

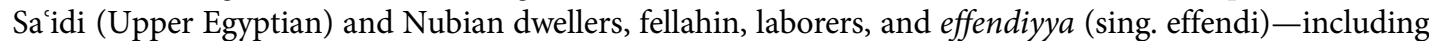
the writer's father himself, an Upper Egyptian clerk-rubbing elbows with "Northerners." ${ }^{5}$ The historical trail of movement from the south can be mapped onto the urban geography. Streets and quarters in Port Said, for instance, carry the names of towns and villages elsewhere. ${ }^{6}$ It may be that Cairo, and in some respects Alexandria, has exerted a hegemonic force upon the rest of the nation, but southern Egyptian migrants have in turn shaped neighborhoods in both locales with their own sociocultural capital and memories.

Scholarly work continues to appear on Cairo and Alexandria; they remain at the core of dominant paradigms of Egyptian history writing. As argued by Peter Gran, virtually all historians handle Egypt as a highly centralized, militarized, and bureaucratic country, in which change comes from the top down and moves

\footnotetext{
${ }^{1}$ Ahmed Naji and Ayman al-Zorkany, Using Life, trans. Benjamin Koerber (Austin, TX: University of Texas Press, 2017). See also Samia Mehrez, The Literary Life of Cairo: One Hundred Years in the Heart of the City (Cairo: American University in Cairo Press, 2016).

${ }^{2}$ Amitav Ghosh, In an Antique Land (London: Granta, 2012), 32.

${ }^{3}$ François Moriconi-Ebrard, "De la crise du centralisme au triomphe des marges," Égypte/Monde arabe, no. 22 (1995): 11-42.

${ }^{4}$ Ghosh, Antique Land, 33.

${ }^{5}$ Idwar al-Kharrat, Turabuha Za'faran: Nusus Iskandaraniyya (Cairo: Dar al-Mustaqbal al-'Arabi, 1986); Deborah A. Starr, Remembering Cosmopolitan Egypt: Literature, Culture, and Empire (New York: Routledge, 2009), 51.

${ }^{6}$ Dia el-Dine Hassan el-Kady, Mawsuu'at Tarikh Bur Sa'id (Cairo: al-Hay'a al-Missriyya al-'Amma li-1-Kitab, 2015), 109-82.

( $)$ The Author(s), 2021. Published by Cambridge University Press. This is an Open Access article, distributed under the terms of the Creative Commons Attribution licence (http://creativecommons.org/licenses/by/4.0/), which permits unrestricted re-use, distribution, and reproduction in any medium, provided the original work is properly cited.
} 
from the city to the rural masses. ${ }^{7}$ Both Arabic and English histories tend to be Cairo-centered, or at least north-centered, a tendency that notable but sporadic works on administration of the provinces have not successfully dislodged. ${ }^{8}$ Although Cairo and Alexandria remain highly relevant to the political, social, and cultural history of modern Egypt, the politically driven disparity in representation of Egypt's towns and provinces has produced a historiographical imbalance that calls for an overdue redress. ${ }^{9}$ Historians elsewhere have long recognized the difficulties of studying regions using state-centered geographies. ${ }^{10}$

Recent works demonstrate the significance of geographically peripheral places and regions. In 2004, Nicholas Hopkins and Reem Saad called for renewed scholarly attention to Upper Egypt, the south of the country. ${ }^{11}$ Their plea was embraced by Zeinab Abul-Magd in her micro-historical examination of the southern province of Qena, and by Nancy Reynolds in her study of the southern city of Aswan. ${ }^{12}$ In this roundtable, both Abul-Magd and Gran center their contributions on sites in Egypt's southern regions: Qena and its surroundings, and Asyut. Heading north along the Nile, Majid 'Izzat Isra'il has researched the history of Helwan. ${ }^{13}$ Hannan Hammad grounded her sociocultural history of industrial urbanization and changing gender norms in the Delta city of Mahalla al-Kubra. ${ }^{14}$ Stephanie Boyle, in her study of cholera in the 19th-century, focused her attention on Tanta, also in the Delta, to illustrate how local histories and global discourses informed one another. Tanta, in dialogue with Alexandria, has also been studied by Elena Chiti in her examination of al-Ahram's press coverage of murderous women. ${ }^{15}$ Zoe Griffith chose Rosetta and Damietta to study the position of Egypt within the Ottoman Empire, and Damietta also was the new focus of Radi Muhammad Jawda's research (following his history of Suez). ${ }^{16}$ Heading west along the seacoast, Matthew Ellis looked at Egypt's sovereignty and administration through the lens of its oases and the Mediterranean coastlines along the country's northwestern border. ${ }^{17}$ Historians Zayn 'Abidin Shams al-Din Najm, 'Abd al-'Aziz Muhammad Shinnawi, Mustafa al-Hifnawi, and Fu'ad Faraj have produced extensive scholarship on the history of the Suez Canal in the northeast. ${ }^{18}$ Beth Baron's recent work on the interactions between missionaries, the Muslim

\footnotetext{
${ }^{7}$ Peter Gran, "Upper Egypt in Modern History: A 'Southern Question'?," in Upper Egypt: Identity and Change, Nicholas S. Hopkins and Reem Saad (Cairo: American University in Cairo Press, 2004), 80.

${ }^{8}$ Zeinab Abul-Magd, Imagined Empires: A History of Revolt in Egypt (Berkeley, CA: University of California Press, 2016), 7. For examples of such works, see Ibrahim Amin Ghali, Sina' al-Misriyya 'Abra al-Tarikh (Cairo: al-Hay'a al-Misriyya al-'Amma li-1-Kitab, 1976); Hilmi Ahmad Shalabi, al-Hukm al-Mahalli wa-l-Majalis al-Baladiyya fi Misr Mundhu Nash'atiha Hatta 'Am 1918 (Cairo: 'Alam al-Kutub, 1987); and Zayn al-'Abidin Shams al-Din Najm, Idarat al-Aqalim fi Misr, 18051882 (Cairo: Dar al-Kitab al-Jami'i, 1988).

${ }^{9}$ See panel titled "Provincializing the Core: Impact of Provincial History on Egyptian National History, 1850s to 1920s," organized by Stephanie Boyle, annual meeting of Middle East Studies Association, 2016.

${ }^{10}$ Eric Tagliacozzo, Secret Trades, Porous Borders: Smuggling and States along a Southeast Asian Frontier, 1865-1915 (New Haven, CT: Yale University Press, 2005), 19.

${ }^{11}$ Nicholas S. Hopkins and Reem Saad, Upper Egypt: Identity and Change (Cairo: American University in Cairo Press, 2004); Nasir Ibrahim, al-Rafd wa-l-Ihtijaj fi al-Mujtama al-Misri fi al-'Asr al-'Uthmani (Cairo: Markaz al-Buhuth wa-1-Dirasat al-Ijtima iyya, 2004).

${ }^{12}$ Abul-Magd, Imagined Empires; Nancy Y. Reynolds, "City of the High Dam: Aswan and the Promise of Postcolonialism in Egypt," City \& Society 29, no. 1 (2017): 213-35.

${ }^{13}$ 'Izzat Isra'il Majid, Madinat Hulwan 'Abra al-Tarikh (Cairo: al-'Arabi li-l-Nashr wa-l-Tawzi', 2018).

${ }^{14}$ Hanan Hammad, Industrial Sexuality: Gender, Urbanization, and Social Transformation in Egypt (Austin, TX: Texas University Press, 2016).

${ }^{15}$ Stephanie Anne Boyle, "Cholera, Colonialism, and Pilgrimage: Exploring Global/Local Exchange in the Central Egyptian Delta, 1848-1907," Journal of World History 26, no. 3 (2016): 604; Elena Chiti, "Building a National Case in Interwar Egypt: Raya and Sakina's Crimes through the Pages of al-Ahram (Fall 1920)," History Compass 18, no. 2 (2020): e12607.

${ }^{16}$ Zoe Ann Griffith, "Egyptian Ports in the Ottoman Mediterranean, 1760-1820" (PhD diss., Brown University, 2017); Radi Muhammad Jawda, Dumyat fi al-Tarikh al-Hadith (1810-1906) (Cairo: al-Hay’a al-Misriyya al-'Amma li-1-Kitab, 2016); Radi Muhammad Jawda, Madinat al-Tarikh: Dirasa 'Umraniyya wa-Iqtisadiyya wa-Ijitma'iyya wa-Istiratijiyya wa-Idariyya li-l-Madinah fi 'Asr Muhammad 'Ali, (Cairo: Majlis al-A'la al-Thaqafa, 2006).

${ }^{17}$ Matthew H. Ellis, “Anomalous Egypt? Rethinking Egyptian Sovereignty at the Western Periphery," in The Long 1890s in Egypt: Colonial Quiescence, Subterranean Resistance, ed. Marilyn Booth and Anthony Gorman (Edinburgh: Edinburgh University Press, 2014), 169-94; Matthew H. Ellis, Desert Borderland: The Making of Modern Egypt and Libya (Stanford, CA: Stanford University Press, 2018).

${ }^{18} \mathrm{Najm}$, Zayn ‘Abidin Shams al-Din. Būr Sa‘īd: tarikhuha wa-tatawwuruha, mundhu nash'atiha 1859 hatta 'am 1882. (Cairo: Al-Hay'ah al-misrīyah al-'ammah lil-kitab, 1987). Faraj, Fu'ad. Mintaqat Qanal al-Suways wa-mudun al-Qanal Būr Sa‘īd, alSuways, al-Isma'iliya wa-siwaha. (Cairo: Matba'at al-ma'arif wa-maktabuha, 1950). Al-Hifnawi, Mustafa. Qanāt Al-Suways
} 
population, and "Islamic activists" concentrates on events unfolding in both the Canal Zone and, coming full circle, Upper Egypt. ${ }^{19}$ These scholars have successfully begun to decenter Egyptian history.

Although a necessary step, decentering is "not simply a geographic move" that embraces the provinces, as On Barak has recently highlighted. ${ }^{20}$ As Hanan Hammad claims in this roundtable, decentering modern Egyptian history "does not mean downplaying Cairo or simply adding towns to the historiography." Rather, it implies "de-normalizing the historical experiences of Cairo as representative of the experience of the entire country." Accordingly, she argues that only a focus on the everyday life of ordinary people "in the context of their locality" and informed by gender can "give a more realistic assessment of the influence of the bourgeois discourses on a complicated and fluid reality." Beth Baron similarly assigns less centrality to elite voices. She plumbs the depths of the urinary fistulas afflicting women, one of whom, in 1908, walked from Qena, the former Upper Egyptian capital just north of Luxor, to the capital to solicit the help of a renowned gynecologist, Nagib Mahfuz. She overcomes the discussion's sheer geographical boundaries by questioning Cairo's presumed monopoly over knowledge production and pushing "default male bodies" and "elite voices" off their pedestals. She does not leave the historically cumbersome Qasr al-'Ayni hospital out of the picture. But she layers its history with the perspectives of female patients and outsiders. She questions the linkages that weave scattered resources and practices together through the common thread of female bodily pain. Matthew Ellis also lifts his gaze above Cairo to examine the administration of the Egyptian Coast Guard. Not only does he venture onto the seldomtrod shores of Marsa Matruh and Sollum; he also manages to redefine the center as peripheral and the periphery as central. From this western borderland, Egypt appears to him as "a site of interimperial competition in a broader Eastern Saharan context, in which the Ottoman state-usually written out of Egyptian history after the British occupation in 1882-was still a major player." Accordingly, the provincial career of an overlooked governmental institution is key to the cardinal issue of international and imperial involvement in the history of modern Egypt.

Egypt has remained in fraught territory within the Western canon, either pulled into an ancient Egyptian or biblical past used to inform on the contemporary or handled by authors who center Egypt toward its current political sphere of power in Cairo. ${ }^{21}$ These trends have contributed to the paradigm that centers Cairo and the north as the springs of political, economic, and cultural influence. Peter Gran highlights these questions, which are brought into plain light by the biblical Exodus story. Gran argues that, "one finds even today Westerners-including Western scholars-who continue to picture Egypt along the lines of Exodus," neglecting subjects such as provincial studies. He calls for historians to look past these paradigms to the provinces, both geographically and theoretically, and toward new avenues of Egyptian history writing.

For Gran, the absence of the Upper Egyptian city of Asyut in the historiography is an example of the prominence of the Anglo-American paradigm; this contrasts with the keen amount of attention given to provincial cities by the Egyptian scholarly community. Similarly, Zeinab Abul-Magd, in her contribution and her monograph Imagined Empires, realigns the history of early modern Egypt toward a politically strong and independent southern state centered at Qena that was made invisible by the rise of a colonial economy-and particularly long-staple cotton-in the 19th century. That invisibility was lifted at times by rebellions and uprisings, as Abul-Magd succinctly argues. Problematically, these local uprisings live on in the cultural imaginations of Egyptians, wherein the central character of popular Egyptian dramas and film is an Upper Egyptian bandit or rebel. The Upper Egyptian is colonized on the screen as both hero and criminal, but never independent from the larger paradigm of a strong central authority based in the north. As Abul-Magd concludes, "Today, like the rest of the country, the Upper Egyptian margin is fully

wa-mushkilatuha al-mu'asirah. 4 vols. (Cairo: Al-Hay'ah al-misriyah al-'ammah lil-kitab, 2015). Shinnawi, 'Abd al-'Aziz Muhammad. Al-sukhrah fi hafr Qanāt al-Suways. (Alexandria: Munsha'at al-ma'rifah al-hadithah, 1958). Shinnawi, 'Abd al-'Aziz Muhammad. Qanāt al-Suways: wa-al-tayyarat al-siyasiyah allati ahatat bi-insha'iha. (Cairo: Ma'had al-buhūth wa-al-dirasat al-'arabiyah, 1971).

${ }^{19}$ Beth Baron, The Orphan Scandal: Christian Missionaries and the Rise of the Muslim Brotherhood (Stanford, CA: Stanford University Press, 2014), 9.

${ }^{20}$ On Barak, Powering Empire (Oakland, CA: University of California Press, 2020), 8.

${ }^{21} \mathrm{We}$ are thinking of general nonfiction on Egyptian history, such as Peter Hessler, The Buried: An Archaeology of the Egyptian Revolution (New York: Penguin Press, 2019). 
silenced. Without real rebels, southern fictional heroes are imagined and continue to be dramatized on screens for the suppressed masses to watch." The Anglo-American silencing of the provinces and the complex duality of Upper Egypt's visibility on the screen and invisibility in historical narratives of the modern state leave a lot to be desired. Research on the borderlands that challenges the stability of Egyptian territoriality is another means of disrupting aging paradigms of a cohesive national entity. Ellis argues that these types of histories decenter Cairo and can work to tell "stories in from the margins, rather than out from the center." Scholarship on the Sinai and Egypt's border with Sudan may assist in this effort, and these remain verdant areas for future study.

History writing on Egypt is still fueled by the overwhelming sense of presentism in the hold that Cairo has on the scholar, making it an entry point for research and fieldwork in Egypt. This leaves the northern capital with a monopoly on the scholarly work of researchers both in Egypt and abroad. Due to the centralization of archival holdings in the 1950s at the Dar al-Watha'iq al-Qawmiyya (National Archives of Egypt), the majority of research, even on provincial questions, still needs to be done at institutions that call Cairo home. ${ }^{22}$ This has fueled the rise of new writing on the difficulty of accessing national archives. ${ }^{23}$ The further securitization of the archival site has left researchers waiting years for admittance, forcing creative uses of different archival sources in Cairo, the provinces, and outside of Egypt. ${ }^{24}$

Beth Baron points out that we must avoid being "bedazzled" by the repositories of Dar al-Watha'iq and turn to the wealth of primary source materials that remain outside of that purview. Further, Baron notes that scholars "have only begun to scratch the surface in analyzing the scientific books and journal articles produced by Egyptian doctors, engineers, scientists, and social scientists." 25 Likewise, Hanan Hammad argues pointedly that, although the Dar al-Watha'iq is still the major archive for all research on Egypt, there are in the provinces archival spaces, private libraries, and personal or family collections that remain understudied. ${ }^{26}$ Court records that detail narratives of theft and complex domestic situations for Hammad, as well as, for Baron, medical articles regarding fistula procedures for Egyptian women, push up against the hegemony of Dar al-Watha'iq as the center of archival material. Moving outside of archives stored in Egypt there also is a wealth of sources, some only recently utilized. Ellis has demonstrated to Egyptian historians the richness of the Abbas Hilmi II Archives at Durham University (in the UK) and possibilities for use of the Italian archives. Company archives established by foreign entities in Egypt whose papers were kept outside of the country offer an abundance of sources that can be read with an eye to avoid falling prey to the institutional or colonial narrative. Ellis questions "which archives allow for the more expansive, decentered approach to Egyptian history" and might generate new perspectives. Examples of this type of historical writing can be found in the recent dissertations on the cities of the Suez Canal by Lucia Carminati and Mohamed Gamal-Eldin. ${ }^{27}$

\footnotetext{
${ }^{22}$ Yoav Di-Capua, Gatekeepers of the Arab Past: Historians and History Writing in Twentieth-Century Egypt (Berkeley, CA: University of California Press, 2009), 294.

${ }^{23}$ Aya Nassar, "Where the Dust Settles: Fieldwork, Subjectivity and Materiality in Cairo," Contemporary Social Science 13, no. 3-4 (2018): 412-28; Pascale Ghazaleh, Past Imperfect, Future Tense: Writing People's Histories in the Middle East Today, vol. 5 (Berlin: Transregionale Studien, 2019); Lucia Carminati, "Dead Ends In and Out of the Archive: An Ethnography of Dar al-Watha'iq al-Qawmiyya, the Egyptian National Archive,” Rethinking History 23, no. 1 (2019): 34-51.

${ }^{24}$ See Matthew Ellis, Hanan Hammad, and Beth Baron in this roundtable for different archival avenues. Also, HAZINE is a valuable online resource for both digital archives and other sites across Egypt and the Middle East. For instance, see Amy Fallas, "Researching Modern Egypt Online," 26 June 2020, http://hazine.info/researching-modern-egypt-online/? fbclid=IwAR3Umt_MKUOsJxeTHGG8DpZJ1FRwtszIatztsF3CaVCay0E_RdMx8V25Qpo. See also the Alexandria Library's recent digitization project at http://modernegypt.bibalex.org/collections/home/default.aspx.

${ }^{25}$ Omnia El Shakry and Mohamed Gamal-Eldin have used published scientific materials as sources for writing on modern Egypt. Omnia S. El Shakry, The Great Social Laboratory: Subjects of Knowledge in Colonial and Postcolonial Egypt (Stanford, CA: Stanford University Press, 2007); Omnia El Shakry, Arabic Freud: Psychoanalysis and Islam in Modern Egypt (Princeton, NJ: Princeton University Press, 2017); Mohamed Gamal-Eldin, “Cesspools, Mosquitos and Fever: An Environmental History of Malaria Prevention in Isma'iliyya and Port Sa'id, 1869-1910," in Seeds of Power: Explorations in Ottoman Environmental History, ed. Onur Inal and Yavuz Kose (London: White Horse Press, 2019), 184-207.

${ }^{26}$ Hammad, Industrial Sexuality.

${ }^{27}$ Lucia Carminati, "Bur Sa'id/Port Said, 1859-1900: Migration, Urbanization, and Empire in an Egyptian and Mediterranean Port-City.” (PhD diss., University of Arizona, 2018); Mohamed Gamal-Eldin, "Cities of Sand: Reshaping the Environment, Building Towns and Finding Modernity in the Isthmus of Suez, 1856-1936” (PhD diss., New Jersey Institute of Technology, 2020).
} 
Ultimately, this roundtable suggests approaches to addressing the imbalance that remains in Egyptian history writing and points out a few ways to overcome the centripetal forces of Cairo and Alexandria. The five contributors do so not just to explore new geographies, but also to challenge perceptions and perspectives. They continue the process of "provincializing," all the while acknowledging the weighty burden that Cairo-and by extension the north-has placed upon Egyptian history. ${ }^{28}$ In so doing, they consider both logistics and ethics. For example, where and how can research in and on Egypt take place in view of quickly evolving local and global circumstances, ranging from capillary repression to boundary-shutting pandemics and politics? How, asks Hammad, can historians, and academics in general, help counter the smuggling of documents and artifacts outside of Egypt? How can scholars based in European and US institutions avoid putting local collaborators at risk, acknowledge their labor commensurately, and be cognizant of the potential impact of their research on others? ${ }^{29}$ Paths that remain unexplored are methodological and thematic. Thinking about Egypt within the broader perspective of the Middle East, North Africa, and the global South points to possibilities illuminated by other national historiographies. Furthermore, race, the environment, and Coptic history (to mention only a few possibilities) may open up new ways of decentering Egypt in its entirety. ${ }^{30}$ Rather than reassembling north and south, center and periphery to make "the country seem to be one harmonious whole," as Gran puts it, this collective conversation calls for sutures that both show their stitches and acknowledge that some areas continue to need healing.

Acknowledgments. This roundtable first convened in person at the 2019 annual meeting of the Middle East Studies Association. We would like to thank the contributors, Zeinab Abul-Magd, Beth Baron, Matthew Ellis, Peter Gran, and Hanan Hammad, for their enthusiasm, patience, and support in pursuit of challenging the ways scholarship on modern Egypt is produced.

\footnotetext{
${ }^{28}$ Dipesh Chakrabarty, Provincializing Europe: Postcolonial Thought and Historical Difference (Princeton, NJ: Princeton University Press, 2000).

${ }^{29}$ For a combined reflection on Ahmad Naji's work, the risks and ethics of fieldwork, and the possible implications for Egyptian interlocutors, see Teresa Pepe, "La ricerca sul campo al tempo dei processi alla scrittura. Il caso di Ahmed Nagi," in Minnena: l'Egitto, l'Europa e la ricerca dopo l'assassinio di Giulio Regeni, Lorenzo Casini, Daniela Melfa, and Paul Starkey (Messina: Mesogea, 2019), 52-79.

${ }^{30}$ See, for example, forthcoming dissertations by Chloe Bordewich, Amy Fallas, and Taylor Moore. See also Amy Fallas, "Assessing Coptic Reform through the International Christian Student Movement," Coptic Canadian History Project, 28 October 2018, https://thecchp.com/2018/10/28/assessing-coptic-reform.
}

Cite this article: Carminati L, Gamal-Eldin M (2021). Decentering Egyptian Historiography: Provincializing Geographies, Methodologies, and Sources. International Journal of Middle East Studies 53, 107-111. https://doi.org/10.1017/ S0020743821000015 